\title{
Application of Nano-Fluids as Coolant in Heat Exchangers: A Review
}

\author{
M. A. Khattak ${ }^{1, *}$, A. Mukhtar ${ }^{2}$, S. Kamran Afaq ${ }^{2}$ \\ Department of Nuclear Engineering, Faculty of Chemical and Energy Engineering, Universiti Teknologi Malaysia, 81310 Skudai Johor, Malaysia \\ Faculty of Engineering \& Technology, HITEC University, Taxila, Pakistan
}

\section{ABSTRACT}

Nanofluids are important because they enhance heat transfer. Nanofluids are colloidal mixtures of nanometric metallic or ceramic particles in a base fluid, such as water, ethylene glycol or oil. Nanofluids possess immense potential to enhance the heat transfer character of the original fluid due to improved thermal transport properties. In this article, a brief overview has been presented to address the unique features of nanofluids, such as their preparation, heat transfer mechanisms, conduction and convection heat transfer enhancement, etc. About 55 published studies (1976-2015) are reviewed in this paper. It is marked from the literature survey articles that nano fluids performance are the most frequently studied as an efficient coolant for heat exchangers.

Keywords:

Nanofluids, Nanoparticles, Heat Transfer Enhancement, Applications of Nanofluids

Copyright $\odot 2020$ PENERBIT AKADEMIA BARU - All rights reserved

\section{Introduction}

This review gives an overview of Nano-fluid, synthesis of nano-fluid, heat transfer through nanofluids and problems associated with their applications. Nanofluids are a new class of fluids engineered by dispersing nanometer-sized materials (nanoparticles, nanofibers, nanotubes, nanowires, nanorods, nanosheet, or droplets) in base fluids [1-3]. In general, materials can have different properties at the nanoscale (nanometer is one billionth of a meter) than they do at larger size. Some materials become stronger, lighter increased stability or better at conducting electricity or heat or at reflecting light. Others display different magnetic properties or become chemically active in special ways [4] .Nanofluids are nanoscale colloidal suspensions containing condensed nanomaterials. Nanofluids have been found to possess enhanced thermo-physical properties such as thermal conductivity, thermal diffusivity, viscosity, and convective heat transfer coefficients compared to those of base fluids like oil or water [5-12]. Researchers have measured the thermo physical properties of nanofluids while many others used well-known predictive correlations. Their works have been both experimental and theoretical [13]. Applications of nanofluids in industries such

\footnotetext{
*Corresponding author.

E-mail address: muhdadil@utm.my (M. A. Khattak)
}

https://doi.org/10.37934/arms.66.1.818 
as heat exchanging devices appear promising with these characteristics. It has demonstrated great potential applications in many fields.

However, the development and applications of nanofluids may be slowed down by several factors such as long term stability, increase pumping power and pressure drop, nanofluids' thermal performance in turbulent flow and fully developed region, lower specific heat of nanofluids and higher production cost of nanofluids [13]. One of the most important issues is the stability of nanofluids, and it remains a big challenge to achieve desired stability of nanofluids. This paper, we will review the new progress in the methods for preparing stable nanofluids and summarize the stability mechanisms.

In recent years, nanofluids have attracted more and more attention. The main driving force for nanofluids research lies in a wide range of applications. Although some review articles involving the progress of nanofluids investigation were published in the past several years, most of the reviews are concerned of the experimental and theoretical studies of the thermo physical properties or the convective heat transfer of nanofluids. The purpose of this paper will focuses on the new preparation methods and stability mechanisms, especially the new application trends for nanofluids in addition to the heat transfer properties of nanofluids.

\section{Synthesis of nanofluids}

Preparation of nanofluids is the first key step in applying nano phase particles to changing the heat transfer performance of conventional fluids. The nanofluid does not simply refer to a liquidsolid mixture. Some special requirements are necessary, such as even suspension, stable suspension, durable suspension, low agglomeration of particles and no chemical change of the fluid. Generally, these are effective methods used for preparation of suspensions: (1) to change the $\mathrm{pH}$ value of suspensions; (2) to use surface activators and/or dispersants; (3) to use ultrasonic vibration. All these techniques aim at changing the surface properties of suspended particles and suppressing formation of particles cluster in order to obtain stabile suspensions. It depends upon the application case how these techniques are used.

Different methods have been developed to prepare nanofluids, such as the dispersing method $[14,6,15-17]$, physical vapor condensation [18, 19], and one-step chemical method [20] etc. However, preparation of a uniformly dispersed nanofluid is essential for obtaining stable reproduction of physical properties or superior characteristics of the nanofluids [21, 22].

\subsection{Two-Step Method}

Two-step method is the most widely used method for preparing nanofluids. Nanoparticles, nanofibers, nanotubes, or other nanomaterials used in this method are first produced as dry powders by chemical or physical methods. Then, the nano sized powder will be dispersed into a fluid in the second processing step with the help of intensive magnetic force agitation, ultrasonic agitation, highshear mixing, homogenizing, and ball milling [23]. Two-step method is the most economic method to produce nanofluids in large scale, because nano powder synthesis techniques have already been scaled up to industrial production levels [24].

Literature review reveals that the initially nanofluids, used a two-step process [14], In which nanoparticles or nanotubes are first produced as a dry powder, often by inert gas condensation [25]. Chemical vapor deposition has also been used to produce constituents for use in nanofluids, particularly multi walled carbon nanotubes [21]. The nanoparticles or nanotubes are then dispersed into a fluid in a second processing step. Simple techniques such as ultrasonic agitation or the addition 
of surfactants to the fluids are sometimes used to minimize particle aggregation and improve dispersion behavior. Such a two-step process works well in some cases, such as nanofluids consisting of oxide nanoparticles dispersed in deionized water [14]. Less success has been found when producing nanofluids containing heavier metallic nanoparticles. Since nano powder synthesis techniques have already been scaled up to industrial production levels by several companies[26], there are potential fiscal advantages in using two-step synthesis methods that rely on the use of such powders.

Literature shows that, there are three effective procedures used to achieve stability of suspension against sedimentation of nanoparticles. Some of the researchers applied all of these methods to gain better stability [27-29], but others just applied one [30] or two techniques with satisfaction [31-33]. There is no standard to recognize the superlative mix up of combining methods. This area acquires more experiments to be clarified.

\subsection{One-Step Method}

To decrease the cluster of nanoparticles, Eastman et al. developed a one-step physical vapor condensation method to prepare $\mathrm{Cu} /$ ethylene glycol nanofluids [19]. The one-step process consists of simultaneously making and dispersing the particles in the fluid. In this method, the processes of drying, storage, transportation, and dispersion of nanoparticles are avoided, so the agglomeration of nanoparticles is minimized, and the stability of fluids is increased [34]. The one-step processes can prepare uniformly dispersed nanoparticles, and the particles can be stably suspended in the base fluid.

However, there are some disadvantages for one-step method. The most important one is that the residual reactants are left in the nanofluids due to incomplete reaction or stabilization. It is difficult to elucidate the nanoparticle effect without eliminating this impurity effect. The preparation of nanofluids with controllable microstructure is one of the key issues. The nanofluid microstructure can be varied and manipulated by adjusting synthesis parameters such as temperature, acidity, ultrasonic and microwave irradiation, types and concentrations of reactants and additives, and the order in which the additives are added to the solution $[35,36]$.

\section{Heat Transfer Characteristics of Nanofluids}

\subsection{Conduction}

Since thermal conductivity is the most important parameter responsible for enhanced heat transfer many experimental works been reported on this aspect. The transient hot wire method[37], the steady-state parallel-plate technique [38] and the temperature oscillation technique have been employed to measure the thermal conductivity of nanofluids [39]. Among them the transient hot wire method has been used most extensively. Because in general nanofluids are electrically conductive, it is difficult to apply the ordinary transient hot-wire technique directly. A modified hotwire cell and electrical system was proposed, Coating the hot wire with an epoxy adhesive which has excellent electrical insulation and heat conduction. However, researcher pointed that possible concentration of ions of the conducting fluids around the hot wire may affect the accuracy of such experimental results.

Oscillation technique was developed and later modified $[40,41]$. This method is purely thermal and the electrical components of the apparatus are removed from the test sample. Hence ion movement should not affect the measurement. 


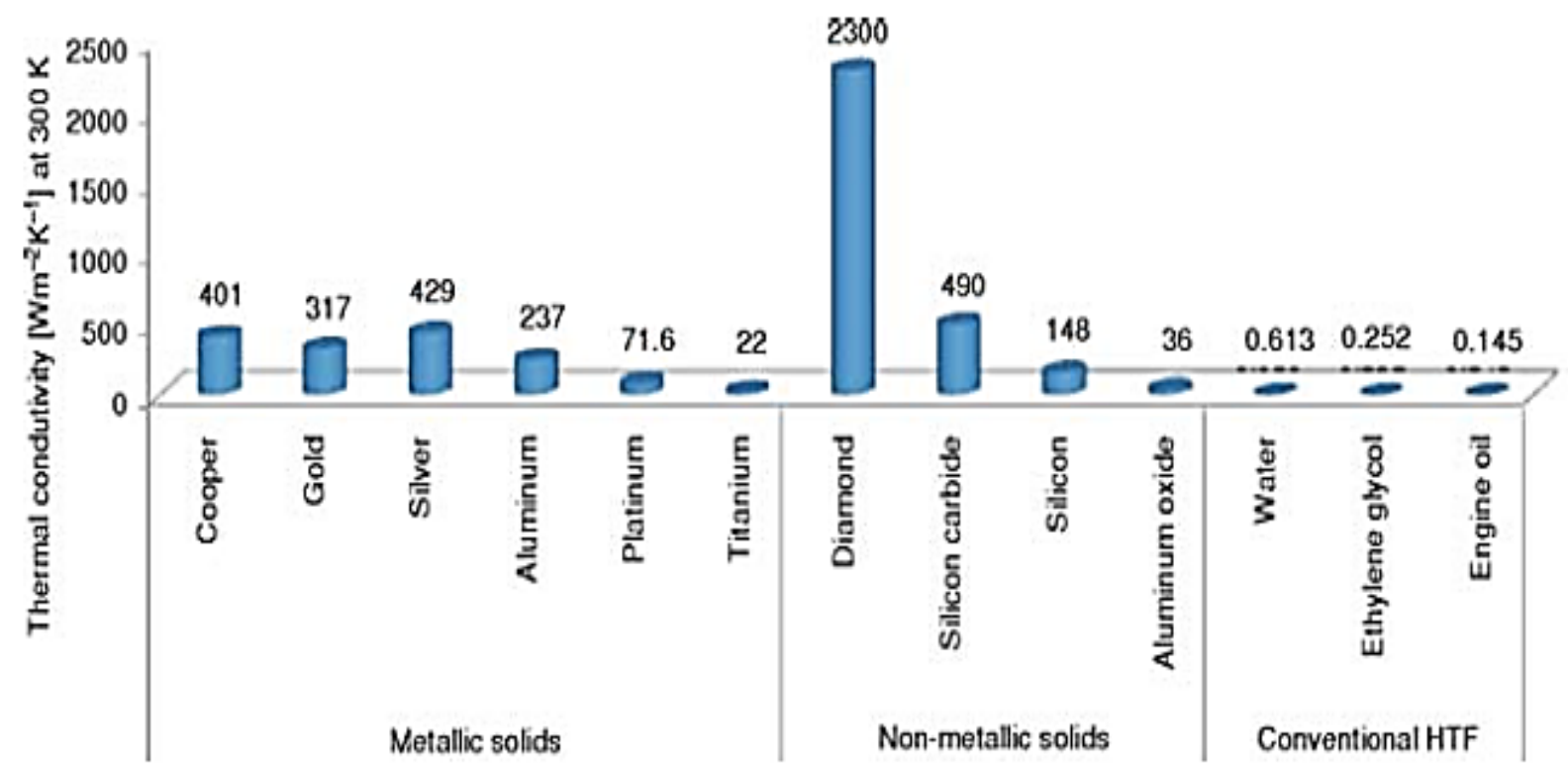

Fig. 1. Effect of Different Materials on thermal conductivity [42]

The experimental results for different nanofluids by researchers are summarized in Table 1 , illustrated the conductive heat transfer coefficient nanoparticles in liquid and shows overall trend of heat transfer enhancement.

Table 1

Effect of Different particles on thermal conductivity [43]

\begin{tabular}{|c|c|c|c|c|c|}
\hline & Particle & Base fluid & $\begin{array}{l}\text { Average particle } \\
\text { size }\end{array}$ & Volume fraction & $\begin{array}{l}\text { Thermal } \\
\text { conductivity } \\
\text { enhancement }\end{array}$ \\
\hline \multirow{6}{*}{$\begin{array}{l}\text { Metallic } \\
\text { nanoparticles }\end{array}$} & $\mathrm{Cu}$ & \multirow[t]{3}{*}{ Ethylene glycol } & $10 \mathrm{~nm}$ & $0.3 \%$ & $40 \%$ \\
\hline & & & & $7.5 \%$ & $78 \%$ \\
\hline & $\mathrm{Cu}$ & & $100 \mathrm{~nm}$ & $0.55 \%$ & $21 \%$ \\
\hline & $\mathrm{Fe}$ & Water & & $0.001 \%$ & $17 \%$ \\
\hline & $\mathrm{Au}$ & \multirow[t]{2}{*}{ Ethylene glycol } & $10-20 \mathrm{~nm}$ & & \\
\hline & $\mathrm{Ag}$ & & $60-80 \mathrm{~nm}$ & & \\
\hline \multirow{6}{*}{$\begin{array}{l}\text { Non-metallic } \\
\text { nanoparticles }\end{array}$} & $\mathrm{Al}_{2} \mathrm{O}_{3}$ & \multirow[t]{6}{*}{ Water } & $13 \mathrm{~nm}$ & $4.3 \%$ & $30 \%$ \\
\hline & $\mathrm{Al}_{2} \mathrm{O}_{3}$ & & $33 \mathrm{~nm}$ & $4.3 \%$ & $15 \%$ \\
\hline & $\mathrm{Al}_{2} \mathrm{O}_{3}$ & & $68 \mathrm{~nm}$ & $5 \%$ & $21 \%$ \\
\hline & $\mathrm{CuO}$ & & $36 \mathrm{~nm}$ & $3.4 \%$ & $12 \%$ \\
\hline & $\mathrm{CuO}$ & & $50 \mathrm{~nm}$ & $0.4 \%$ & $17 \%$ \\
\hline & $\mathrm{SiC}$ & & $26 \mathrm{~nm}$ & $4.2 \%$ & $16 \%$ \\
\hline
\end{tabular}

The maximum measured thermal conductivity enhancement for different nanofluids is summarized in Table 2. 
Table 2

Summary of the maximum measured thermal conductivity enhancement for nanofluids contacting nanoparticles

\begin{tabular}{|c|c|c|c|c|c|}
\hline Base Fluid & Nano Particle & $\begin{array}{c}\text { Size of } \\
\text { particles } \\
(\mathrm{nm})\end{array}$ & $\begin{array}{c}\text { Maximum } \\
\text { Concentration } \\
\text { (vol \%) }\end{array}$ & $\begin{array}{c}\text { Maximum } \\
\text { Enhancement in } k \\
(\%)\end{array}$ & Reference \\
\hline Water & $\mathrm{Al}_{2} \mathrm{O}_{3}$ & $13 \mathrm{~nm}$ & 4.3 & 30 & {$[44]$} \\
\hline Water & $\mathrm{Al}_{2} \mathrm{O}_{3}$ & 33 & 5 & 30 & \multirow{3}{*}[5]{} \\
\hline Water & $\mathrm{CuO}$ & 36 & 5 & 60 & \\
\hline Pump Oil & $\mathrm{Cu}$ & 35 & 0.055 & 45 & \\
\hline Water & $\mathrm{Al}_{2} \mathrm{O}_{3}$ & 13 & 4.3 & 32 & \multirow{2}{*}[45]{} \\
\hline Water & $\mathrm{TiO}_{2}$ & 27 & 4.35 & 10.7 & \\
\hline Water & $\mathrm{Al}_{2} \mathrm{O}_{3}$ & 28 & 4.5 & 14 & \multirow{6}{*}[38]{} \\
\hline Ethylene Glycol & $\mathrm{Al}_{2} \mathrm{O}_{3}$ & 28 & 8 & 40 & \\
\hline Pump Oil & $\mathrm{Al}_{2} \mathrm{O}_{3}$ & 28 & 7 & 20 & \\
\hline Engine Oil & $\mathrm{Al}_{2} \mathrm{O}_{3}$ & 28 & 7.5 & 30 & \\
\hline Water & $\mathrm{CuO}$ & 23 & 10 & 35 & \\
\hline Ethylene Glycol & $\mathrm{CuO}$ & 23 & 15 & 55 & \\
\hline Water & $\mathrm{Al}_{2} \mathrm{O}_{3}$ & 24.4 & 4.3 & 10 & \multirow{4}{*}[14]{} \\
\hline Ethylene Glycol & $\mathrm{Al}_{2} \mathrm{O}_{3}$ & 24.4 & 5 & 20 & \\
\hline Water & $\mathrm{CuO}$ & 18.6 & 4.3 & 10 & \\
\hline Ethylene Glycol & $\mathrm{CuO}$ & 18.6 & 4 & 20 & \\
\hline Water & $\mathrm{Al}_{2} \mathrm{O}_{3}$ & 38 & 4 & 25 & \multirow{2}{*}{ [39] } \\
\hline Water & $\mathrm{CuO}$ & 28.6 & 4 & 36 & \\
\hline Water & $\mathrm{Al}_{2} \mathrm{O}_{3}$ & 60 & 5 & 20 & \multirow{3}{*}[46]{} \\
\hline Ethylene Glycol & $\mathrm{Al}_{2} \mathrm{O}_{3}$ & 60 & 5 & 30 & \\
\hline Pump Oil & $\mathrm{Al}_{2} \mathrm{O}_{3}$ & 60 & 5 & 40 & \\
\hline Water & $\mathrm{Al}_{2} \mathrm{O}_{3}$ & 10 & 0.5 & 100 & [47] \\
\hline Water & $\mathrm{Al}_{2} \mathrm{O}_{3}$ & 20 & 1 & 16 & {$[48]$} \\
\hline Ethylene Glycol & $\mathrm{CuO}$ & 25 & 5 & 22.4 & {$[49]$} \\
\hline Water & $\mathrm{TiO}_{2}$ & 15 & 5 & 33 & {$[50]$} \\
\hline Toluene & $\mathrm{Au}$ & 15 & 0.011 & 8.8 & \multirow{3}{*}[22]{} \\
\hline Water & $\mathrm{Au}$ & 15 & 0.00026 & 8.3 & \\
\hline Water & $\mathrm{Ag}$ & 70 & 0.001 & 4.5 & \\
\hline Ethylene Glycol & $\mathrm{Fe}$ & 10 & 0.55 & 18 & {$[51,52]$} \\
\hline
\end{tabular}

\subsection{Convection}

Researchers presented an experimental system to investigate the convective heat transfer coefficient and friction factor of nanofluids for laminar and turbulent flows in a tube $[53,54]$. The working fluid used was $100 \mathrm{~nm}$ Cu particles dispersed in deionized water. Experiments with different concentrations of nanoparticles were conducted. The Reynolds number of the nanofluids varied in the range of 800-25000. The nanofluid used consisted of $\mathrm{Fe}_{3} \mathrm{O}_{4}$ magnetic nanoparticles with an average diameter of $13 \mathrm{~nm}$ dispersed in water with six volume fractions $(0,0.6,0.8,1,1.5$ and $2 \%)$. The results revealed that as volume fraction and Reynolds number increased, Nusselt number increased, and friction factor decreased as Reynolds number increased [55] .The experimental results concluded that the convective heat transfer coefficient of the nanofluids varied with the flow velocity 
and volume fraction. Also, the values were higher than those of the base fluid in the same conditions. The Nusselt number of the nanofluids with $2 \%$ volume fraction of $\mathrm{Cu}$ particles was $60 \%$ higher than that of water. From the experimental data of [54,53], the new heat transfer correlations for the prediction of the heat transfer coefficient of nanofluids flowing in a tube were given as follows:

Laminar flow:

$$
N u_{n f}=0.4329\left[1.0+11.285 \phi^{0.754} P e_{d}^{0.218}\right] \operatorname{Re}_{n f}^{0.33} \operatorname{Pr}_{n f}^{0.4}
$$

Turbulent flow:

$$
N u_{n f}=0.0059\left[1.0+7.6286 \phi^{0.6886} P e_{d}^{0.001}\right] \operatorname{Re}_{n f}^{0.9233} \operatorname{Pr}_{n f}^{0.4}
$$

where

$$
\begin{aligned}
& P e_{d}=\frac{u_{m} d_{p}}{\alpha_{n f}} ; \operatorname{Re}_{n f}=\frac{u_{m} D}{v_{n f}} ; \operatorname{Pr}_{n f}=\frac{v_{n f}}{\alpha_{n f}} \\
& \alpha_{n f}=\frac{k_{n f}}{\left(\rho C_{p}\right)_{n f}}=\frac{k_{n f}}{(1-\phi)\left(\rho C_{p}\right)_{f}+\phi\left(\rho C_{p}\right)_{d}}
\end{aligned}
$$

The results indicated that the friction factor of the nanofluids was equal to that of water under some working conditions, and did not vary with volume fraction. This shows that the nanofluid did not increase the pump power. The friction factor of the nanofluids was determined from the following equation

$$
\lambda_{n f}=\frac{\Delta p_{n f} D}{\frac{L^{2} g}{u_{m}^{2}}}
$$

Researcher performed experiments with $\mathrm{Al}_{2} \mathrm{O}_{3}$ and $\mathrm{CuO}$ nanoparticles in water under laminar flow up to turbulence [56]. They found more heat transfer enhancement, as high as $40 \%$, with $\mathrm{Al}_{2} \mathrm{O}_{3}$ particles, while the thermal conductivity enhancement was less than $15 \%$. The Dittus Boelter equation was not valid for the prediction of the Nusselt number of the nanofluids at various volume fractions. Figures 2 and 3 show the performance of different nanofluids on the car radiator. 


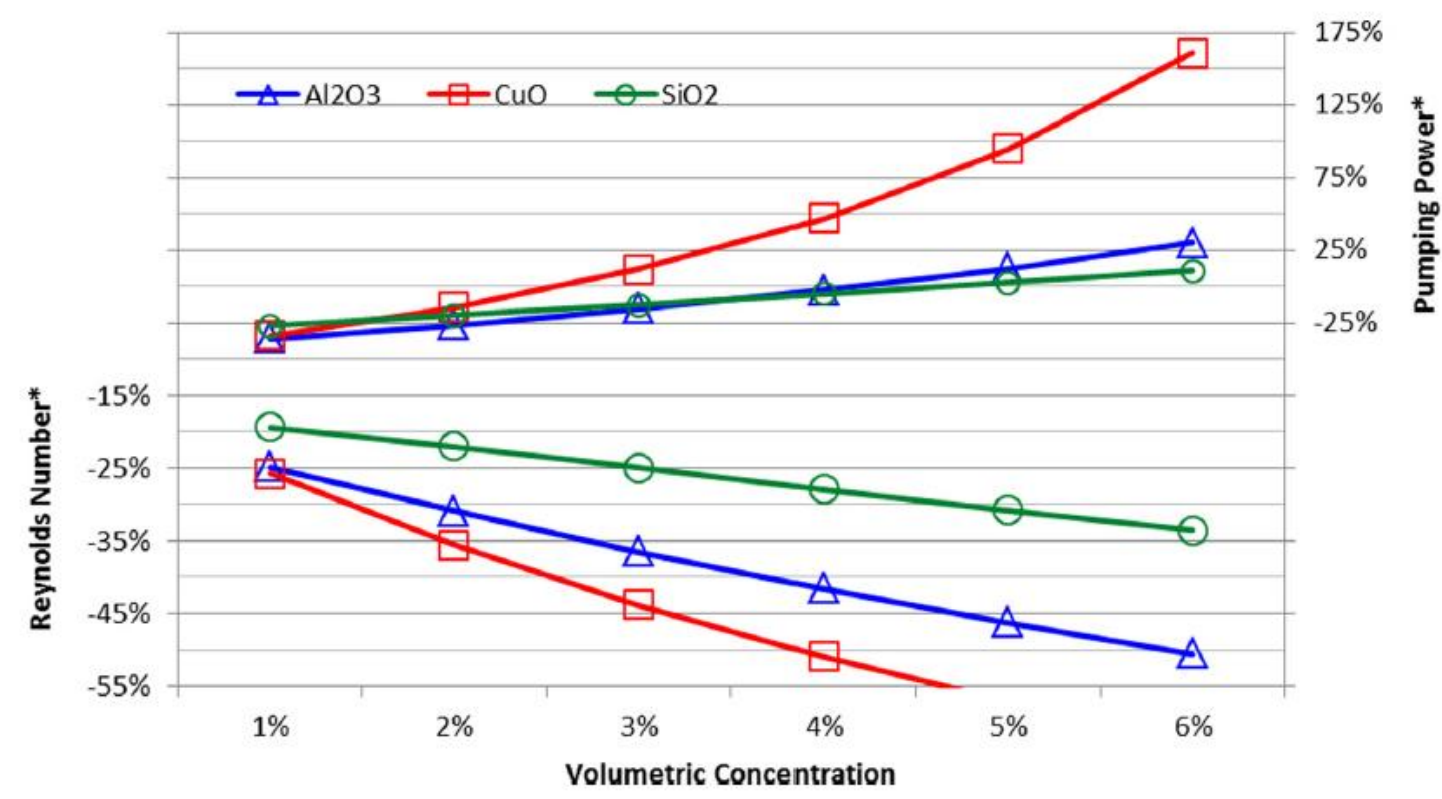

Fig. 2. The effect of volumetric concentration of nanoparticle on the Reynolds number and pumping power compared to the base fluid [57]

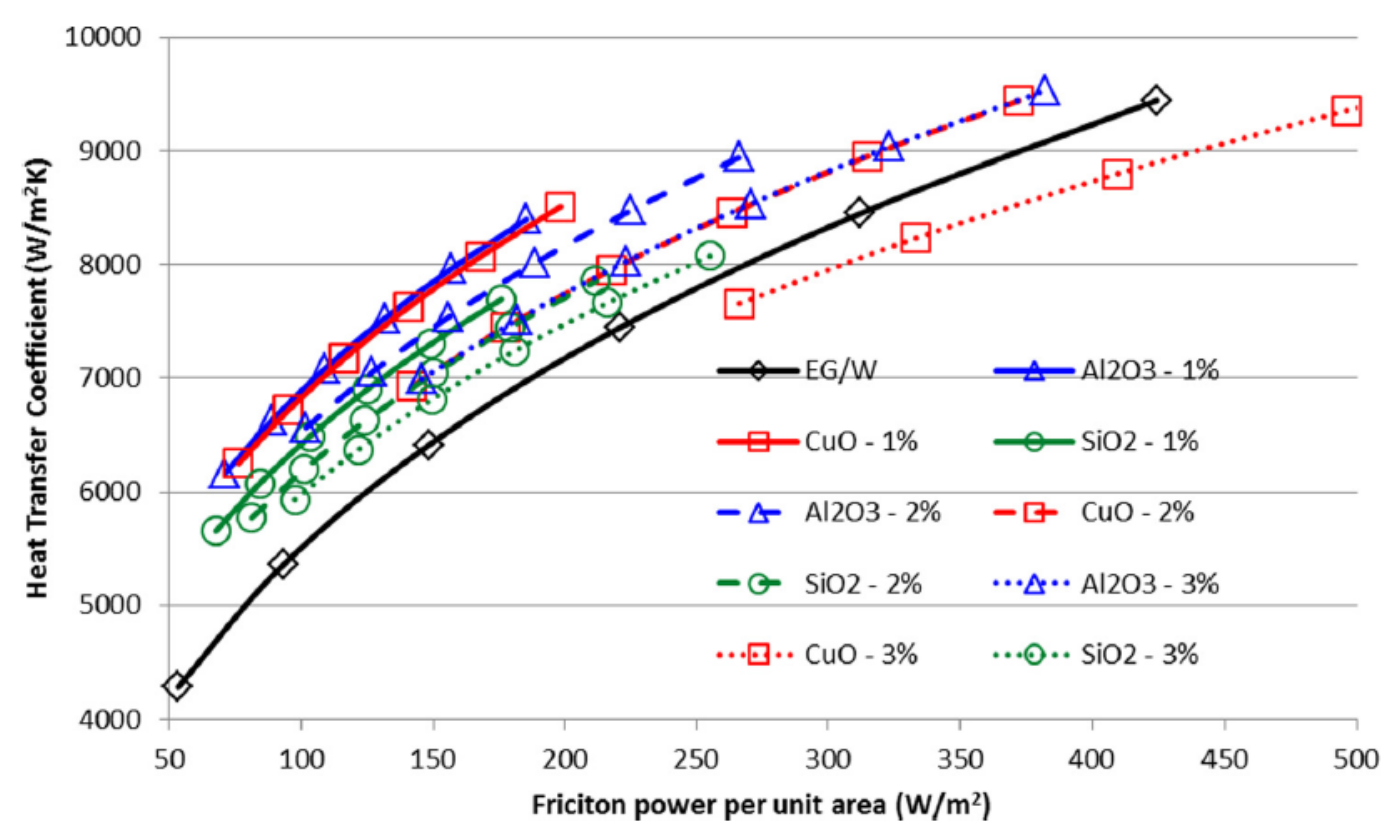

Fig. 3. A comparison of the heat transfer coefficient and friction power per unit area with three nanofluids of $1-3 \%$ concentration and the base fluid [57]

\section{Conclusion}

The current review is a comprehensive outlook on the research progress made in the thermal enhancement process using nanofluids. The aim of the nanofluid research is to develop new methods to augment the synthesis method, novel equipment's for measuring the thermo physical properties and synthesize nanofluids with excellent transport properties. The size of the nanoparticles plays an 
important role in improving the heat transfer properties. The dispersion behavior of nanoparticles improves, if the nanoparticles can be prevented from agglomeration using appropriate surfactants. The mechanism of the temperature dependence of thermal conductivity continues to be a prime research area, where experimental findings are used to substantiate theory and applications.

\section{REFERENCES}

[1] Elsalamony, R.A., R.E. Morsi, and A.M. Alsabagh. "Preparation, Stability and Photocatalytic Activity of Titania Nanofluid Using Gamma Irradiated Titania Nanoparticles by Two-Step Method."

[2] Azimi, H., and R. Taheri. "Electrical Conductivity of Cuo Nanofluids." International Journal of Nano Dimension 6, no. 1 (2015): 77.

[3] Bég, O.A., and D. Tripathi. "Mathematica Simulation of Peristaltic Pumping with Double-Diffusive Convection in Nanofluids: A Bio-Nano-Engineering Model." Proceedings of the Institution of Mechanical Engineers, Part N: Journal of Nanoengineering and Nanosystems (2012): 1740349912437087.

[4] Hussein, A.K. "Applications of Nanotechnology in Renewable Energies-a Comprehensive Overview and Understanding." Renewable and Sustainable Energy Reviews 42 (2015): 460-76.

https://doi.org/10.1016/i.rser.2014.10.027

[5] Eastman, J., U. Choi, S. Li, L. Thompson, and S. Lee. "Enhanced Thermal Conductivity through the Development of Nanofluids." Paper presented at the MRS proceedings, 1996. https://doi.org/10.1557/PROC-457-3

[6] Liu, M.S., M.C. Lin, I.T. Huang, and C.C. Wang. "Enhancement of Thermal Conductivity with Cuo for Nanofluids." Chemical engineering \& technology 29, no. 1 (2006): 72-77. https://doi.org/10.1002/ceat.200500184

[7] Hwang, Y., H. Park, J. Lee, and W. Jung. "Thermal Conductivity and Lubrication Characteristics of Nanofluids." Current Applied Physics 6 (2006): e67-e71. https://doi.org/10.1016/j.cap.2006.01.014

[8] Yu, W., H. Xie, L. Chen, and Y. Li. "Investigation of Thermal Conductivity and Viscosity of Ethylene Glycol Based Zno Nanofluid." Thermochimica Acta 491, no. 1 (2009): 92-96.

https://doi.org/10.1016/j.tca.2009.03.007

[9] Mintsa, H.A., G. Roy, C.T. Nguyen, and D. Doucet. "New Temperature Dependent Thermal Conductivity Data for Water-Based Nanofluids." International Journal of Thermal Sciences 48, no. 2 (2009): 363-71. https://doi.org/10.1016/j.ijthermalsci.2008.03.009

[10] Heris, S.Z., M.N. Esfahany, and S.G. Etemad. "Experimental Investigation of Convective Heat Transfer of Al 20 3/Water Nanofluid in Circular Tube." International Journal of Heat and Fluid Flow 28, no. 2 (2007): 203-10. https://doi.org/10.1016/i.ijheatfluidflow.2006.05.001

[11] Kim, D., Y. Kwon, Y. Cho, C. Li, S. Cheong, Y. Hwang, J. Lee, D. Hong, and S. Moon. "Convective Heat Transfer Characteristics of Nanofluids under Laminar and Turbulent Flow Conditions." Current Applied Physics 9, no. 2 (2009): e119-e23. https://doi.org/10.1016/j.cap.2008.12.047

[12] Jung, J.-Y., H.-S. Oh, and H.-Y. Kwak. "Forced Convective Heat Transfer of Nanofluids in Microchannels." International Journal of Heat and Mass Transfer 52, no. 1 (2009): 466-72.

https://doi.org/10.1016/j.ijheatmasstransfer.2008.03.033

[13] Duangthongsuk, W., and S. Wongwises. "Comparison of the Effects of Measured and Computed Thermophysical Properties of Nanofluids on Heat Transfer Performance." Experimental Thermal and Fluid Science 34, no. 5 (2010): 616-24. https://doi.org/10.1016/j.expthermflusci.2009.11.012

[14] Lee, S., S.-S. Choi, S. Li, and, and J. Eastman. "Measuring Thermal Conductivity of Fluids Containing Oxide Nanoparticles." Journal of Heat transfer 121, no. 2 (1999): 280-89. https://doi.org/10.1115/1.2825978

[15] Wen, D., and Y. Ding. "Effective Thermal Conductivity of Aqueous Suspensions of Carbon Nanotubes (Carbon Nanotube Nanofluids)." Journal of Thermophysics and Heat Transfer 18, no. 4 (2004): 481-85. https://doi.org/10.2514/1.9934

[16] Kulkarni, D.P., D.K. Das, and G.A. Chukwu. "Temperature Dependent Rheological Property of Copper Oxide Nanoparticles Suspension (Nanofluid)." Journal of nanoscience and nanotechnology 6, no. 4 (2006): 1150-54. https://doi.org/10.1166/inn.2006.187

[17] Wang, B., L. Zhou, and X. Peng. "A Fractal Model for the Effective Thermal Conductivity of Nanoparticle Suspensions." Progress in Natural Science 14, no. 1 (2004): 36-40. 
https://doi.org/10.1080/10020070412331343111

[18] Choi, S.U., and J.A. Eastman. "Increasing Conductivity of Liquids with Nanofluid by Dispersion of Particles, Evaporation and Adding Thioglycolic Acid." Google Patents, 2001.

[19] Eastman, J.A., S. Choi, S. Li, W. Yu, and L. Thompson. "Anomalously Increased Effective Thermal Conductivities of Ethylene Glycol-Based Nanofluids Containing Copper Nanoparticles." Applied physics letters 78, no. 6 (2001): 718 20.

https://doi.org/10.1063/1.1341218

[20] Zhu, H.-t., Y.-s. Lin, and Y.-s. Yin. "A Novel One-Step Chemical Method for Preparation of Copper Nanofluids." Journal of colloid and interface science 277, no. 1 (2004): 100-03.

https://doi.org/10.1016/i.jcis.2004.04.026

[21] Choi, S., Z. Zhang, W. Yu, F. Lockwood, and E. Grulke. "Anomalous Thermal Conductivity Enhancement in Nanotube Suspensions." Applied physics letters 79, no. 14 (2001): 2252-54. https://doi.org/10.1063/1.1408272

[22] Patel, H.E., S.K. Das, T. Sundararajan, A.S. Nair, B. George, and T. Pradeep. "Thermal Conductivities of Naked and Monolayer Protected Metal Nanoparticle Based Nanofluids: Manifestation of Anomalous Enhancement and Chemical Effects." Applied Physics Letters 83, no. 14 (2003): 2931-33.

https://doi.org/10.1063/1.1602578

[23] Gadekar, R., K. Thakur, and S. Kumbhare. "ZnO a Nanofluid in Radiator to Increase Thermal Conductivity Based on Ethylene Glycol."

[24] Wang, X.-Q., and A.S. Mujumdar. "A Review on Nanofluids-Part li: Experiments and Applications." Brazilian Journal of Chemical Engineering 25, no. 4 (2008): 631-48.

https://doi.org/10.1590/S0104-66322008000400002

[25] Granqvist, C., and R. Buhrman. "Ultrafine Metal Particles." Journal of Applied Physics 47, no. 5 (1976): $2200-19$. https://doi.org/10.1063/1.322870

[26] Romano, J., J. Parker, and Q. Ford. "Application Opportunities for Nanoparticles Made from the Condensation of Physical Vapors." Advances in Powder Metallurgy and Particulate Materials--1997. 2 (1997): 12.

[27] Zhu, D., X. Li, N. Wang, X. Wang, J. Gao, and H. Li. "Dispersion Behavior and Thermal Conductivity Characteristics of Al 2 O 3-H 2 O Nanofluids." Current Applied Physics 9, no. 1 (2009): 131-39.

https://doi.org/10.1016/i.cap.2007.12.008

[28] Wang, X.-j., and D.-s. Zhu. "Investigation of Ph and Sdbs on Enhancement of Thermal Conductivity in Nanofluids." Chemical Physics Letters 470, no. 1 (2009): 107-11.

https://doi.org/10.1016/i.cplett.2009.01.035

[29] Pantzali, M., A. Kanaris, K. Antoniadis, A. Mouza, and S. Paras. "Effect of Nanofluids on the Performance of a Miniature Plate Heat Exchanger with Modulated Surface." International Journal of Heat and Fluid Flow 30, no. 4 (2009): 691-99.

https://doi.org/10.1016/j.ijheatfluidflow.2009.02.005

[30] Chandrasekar, M., S. Suresh, and A.C. Bose. "Experimental Investigations and Theoretical Determination of Thermal Conductivity and Viscosity of Al 20 3/Water Nanofluid." Experimental Thermal and Fluid Science 34, no. 2 (2010): 210-16. https://doi.org/10.1016/i.expthermflusci.2009.10.022

[31] Assael, M., I. Metaxa, J. Arvanitidis, D. Christofilos, and C. Lioutas. "Thermal Conductivity Enhancement in Aqueous Suspensions of Carbon Multi-Walled and Double-Walled Nanotubes in the Presence of Two Different Dispersants." International Journal of Thermophysics 26, no. 3 (2005): 647-64.

https://doi.org/10.1007/s10765-005-5569-3

[32] Wei, X., T. Kong, H. Zhu, and L. Wang. "Cus/Cu 2 S Nanofluids: Synthesis and Thermal Conductivity." International Journal of Heat and Mass Transfer 53, no. 9 (2010): 1841-43.

https://doi.org/10.1016/i.ijheatmasstransfer.2010.01.006

[33] Meibodi, M.E., M. Vafaie-Sefti, A.M. Rashidi, A. Amrollahi, M. Tabasi, and H.S. Kalal. "The Role of Different Parameters on the Stability and Thermal Conductivity of Carbon Nanotube/Water Nanofluids." International Communications in Heat and Mass Transfer 37, no. 3 (2010): 319-23.

https://doi.org/10.1016/i.icheatmasstransfer.2009.10.004

[34] Li, Y., S. Tung, E. Schneider, and S. Xi. "A Review on Development of Nanofluid Preparation and Characterization." Powder Technology 196, no. 2 (2009): 89-101. https://doi.org/10.1016/i.powtec.2009.07.025

[35] Wang, L., and M. Quintard. "Nanofluids of the Future." In Advances in Transport Phenomena, 179-243: Springer, 2009. 
https://doi.org/10.1007/978-3-642-02690-4_4

[36] Wang, L., and X. Wei. "Nanofluids: Synthesis, Heat Conduction, and Extension." Journal of Heat Transfer 131 , no. 3 (2009): 033102.

https://doi.org/10.1115/1.3056597

[37] Kestin, J., and W. Wakeham. "A Contribution to the Theory of the Transient Hot-Wire Technique for Thermal Conductivity Measurements." Physica A: Statistical Mechanics and its Applications 92, no. 1 (1978): 102-16. https://doi.org/10.1016/0378-4371(78)90023-7

[38] Wang, X., X. Xu, and S.U. S. Choi. "Thermal Conductivity of Nanoparticle-Fluid Mixture." Journal of thermophysics and heat transfer 13, no. 4 (1999): 474-80.

https://doi.org/10.2514/2.6486

[39] Das, S.K., N. Putra, P. Thiesen, and W. Roetzel. "Temperature Dependence of Thermal Conductivity Enhancement for Nanofluids." Journal of Heat Transfer 125, no. 4 (2003): 567-74. https://doi.org/10.1115/1.1571080

[40] Roetzel, W., S. Prinzen, and Y. Xuan. "Measurement of Thermal Diffusivity Using Temperature Oscillations." Thermal conductivity 21 (1990): 201-07.

[41] Czarnetzki, W., and W. Roetzel. "Temperature Oscillation Techniques for Simultaneous Measurement of Thermal Diffusivity and Conductivity." International Journal of Thermophysics 16, no. 2 (1995): 413-22. https://doi.org/10.1007/BF01441907

[42] Bergman, T.L., F.P. Incropera, and A.S. Lavine. Fundamentals of Heat and Mass Transfer: John Wiley \& Sons, 2011.

[43] Saidur, R., K. Leong, and H. Mohammad. "A Review on Applications and Challenges of Nanofluids." Renewable and sustainable energy reviews 15, no. 3 (2011): 1646-68. https://doi.org/10.1016/j.rser.2010.11.035

[44] Masuda, H., A. Ebata, and K. Teramae. "Alteration of Thermal Conductivity and Viscosity of Liquid by Dispersing Ultra-Fine Particles. Dispersion of Al2o3, Sio2 and Tio2 Ultra-Fine Particles." (1993).

https://doi.org/10.2963/ijtp.7.227

[45] Pak, B.C., and Y.I. Cho. "Hydrodynamic and Heat Transfer Study of Dispersed Fluids with Submicron Metallic Oxide Particles." Experimental Heat Transfer an International Journal 11, no. 2 (1998): 151-70. https://doi.org/10.1080/08916159808946559

[46] Xie, H., J. Wang, T. Xi, Y. Liu, F. Ai, and Q. Wu. "Thermal Conductivity Enhancement of Suspensions Containing Nanosized Alumina Particles." Journal of Applied Physics 91, no. 7 (2002): 4568-72. https://doi.org/10.1063/1.1454184

[47] Prasher, R., P. Bhattacharya, and P.E. Phelan. "Thermal Conductivity of Nanoscale Colloidal Solutions (Nanofluids)." Physical review letters 94, no. 2 (2005): 025901. https://doi.org/10.1103/PhysRevLett.94.025901

[48] Krishnamurthy, S., P. Bhattacharya, P. Phelan, and R. Prasher. "Enhanced Mass Transport in Nanofluids." Nano Letters 6, no. 3 (2006): 419-23. https://doi.org/10.1021/nl0522532

[49] Liu, M.-S., M.C.-C. Lin, C. Tsai, and C.-C. Wang. "Enhancement of Thermal Conductivity with Cu for Nanofluids Using Chemical Reduction Method." International Journal of Heat and Mass Transfer 49, no. 17 (2006): 3028-33. https://doi.org/10.1016/j.ijheatmasstransfer.2006.02.012

[50] Murshed, S., K. Leong, and C. Yang. "Enhanced Thermal Conductivity of Tio 2-Water Based Nanofluids." International Journal of Thermal Sciences 44, no. 4 (2005): 367-73. https://doi.org/10.1016/ji.ijthermalsci.2004.12.005

[51] Hong, K., T.-K. Hong, and H.-S. Yang. "Thermal Conductivity of Fe Nanofluids Depending on the Cluster Size of Nanoparticles." Applied Physics Letters 88, no. 3 (2006): 031901. https://doi.org/10.1063/1.2166199

[52] Hong, T.-K., H.-S. Yang, and C. Choi. "Study of the Enhanced Thermal Conductivity of Fe Nanofluids." Journal of Applied Physics 97, no. 6 (2005): 064311. https://doi.org/10.1063/1.1861145

[53] Xuan, Y., and Q. Li. "Investigation on Convective Heat Transfer and Flow Features of Nanofluids." Journal of Heat transfer 125, no. 1 (2003): 151-55. https://doi.org/10.1115/1.1532008

[54] Li, Q., and Y. Xuan. "Convective Heat Transfer and Flow Characteristics of Cu-Water Nanofluid." Science in China Series E: Technolgical Science 45, no. 4 (2002): 408-16.

[55] Sidik, C., N. Azwadi, and M. Raad Abdulwahab. "Numerical Investigation of Turbulent Magnetic Nanofluid Flow inside Straight Channels." Paper presented at the Applied Mechanics and Materials, 2016. 
[56] Heris, S.Z., S.G. Etemad, and M.N. Esfahany. "Experimental Investigation of Oxide Nanofluids Laminar Flow Convective Heat Transfer." International Communications in Heat and Mass Transfer 33, no. 4 (2006): 529-35. https://doi.org/10.1016/i.icheatmasstransfer.2006.01.005

[57] Ray, D.R., and D.K. Das. "Superior Performance of Nanofluids in an Automotive Radiator." Journal of Thermal Science and Engineering Applications 6, no. 4 (2014): 041002.

https://doi.org/10.1115/1.4027302 